\title{
FAKTOR-FAKTOR YANG MEMPENGARUHI TERJADINYA ALIH FUNGSI LAHAN PERTANIAN DI KABUPATEN MINAHASA TENGGARA
}

\author{
Christianto Pondaag \\ Caroline B. D. Pakasi \\ Ribka M. Kumaat
}

\begin{abstract}
The research was purposed to analysis factors that affecting to land conversion from agriculture to non agriculture at Southeast Minahasa Regency. Variables are in analysis is total population, PDRB capita and total industries. This research was done by used secondary data obtained from Central Statistics Agency of Southeast Minahasa Regency. Secondary data collected are Total population, PDRB per capita and total industries in Southeast Minahasa Regency by times series data. Data analysis is done using multiple linear analysis. The result research showed that only Population which affecting significantly to the decrease the land of agriculture area in Southeast Minahasa Regency. Increasing total population make a demand for the land of residence area continues to increase. That impact on the land of agriculture area was tends to decrease.*inkd*
\end{abstract}

Keywords: conversion of agricultural land, Southeast Minahasa Regency.

\begin{abstract}
ABSTRAK
Penelitian ini bertujuan untuk menganalisis faktor-faktor yamg mempengaruhi Terjadinya alih fungsi lahan pertanian ke non pertanian di Kabupaten Minahasa Tenggara. Variabel yang di analisis adalah jumlah Penduduk, PDRB per kapita dan Jumlah Industri. Penelitian ini dilaksanakan dengan menggunakan data sekunder yang di peroleh dari Kantor BPS (Badan Pusat Statistik) Minahasa Tenggara. Data sekunder yang di kumpulkan yaitu Jumlah Penduduk, PDRB per Kapita dan Jumlah Industri di Kabupaten Minahasa Tenggara dengan data Time Series. Analisis data dilakukan menggunakan Analisis Linear Berganda. Hasil penelitian menunjukan hanya jumlah Penduduk yang berpengaruh secara signifikan terhadap penurunan luas lahan pertanian di Kabupaten Minahasa Tenggara. Jumlah Penduduk yang terus meningkat membuat permintaan akan pemukiman semakin bertambah. Akibatnya luas lahan pertanian cenderung semakin menurun.*jnkd*
\end{abstract}

Kata kunci: alih fungsi lahan pertanian, Kabupaten Minahasa Tenggara.

\section{PENDAHULUAN}

\section{Latar Belakang}

Lahan merupakan sumber daya alam strategis bagi pembangunan. Hampir semua sektor pembangunan fisik memerlukan lahan. Seperti, sektor pertanian, kehutanan, perumahan, industri, pertambangan dan transportasi. Di bidang pertanian, lahan merupakan sumber daya yang sangat penting baik bagi petani maupun bagi pembangunan pertanian. Hal ini didasarkan pada kenyataan bahwa di Indonesia kegiatan pertanian masih bertumpu pada lahan pertanian (Catur, 2010). 
Perkembangan kegiatan masyarakat yang membutuhkan lahan sebagai wadahnya meningkat dengan sangat cepat sejalan dengan perkembangan jumlah penduduk dan pertumbuhan ekonomi. Akibatnya terjadi persaingan pemanfaatan lahan, terutama pada kawasan-kawasan yang telah berkembang dimana sediaan lahan relatif sangat terbatas. Pada penggunaan lahan pertanian meskipun lebih lestari kemampuannya dalam menjamin kehidupan petani, tetapi hanya dapat memberikan sedikit keuntungan materi atau finansial dibandingkan sektor industri, permukiman dan jasa lainnya, sehingga adanya alih fungsi lahan pertanian ke penggunaan lainnya tidak dapat dicegah.

Akhir-akhir ini, sejalan dengan meningkatnya taraf hidup dan terbukanya kesempatan untuk menciptakan peluang kerja yang ditandai oleh banyaknya investor ataupun masyarakat dan pemerintah dalam melakukan pembangunan, semakin meningkatkan kebutuhan akan lahan. Peningkatan kebutuhan lahan didorong oleh peningkatan jumlah penduduk, sementara ketersediaan dan luas lahan bersifat tetap. Hal ini mengakibatkan terjadinya perubahan penggunaan lahan dari aktivitas yang kurang menguntungkan pada aktivitas yang lebih menguntungkan. Aktivitas pemanfaatan lahan yang selalu terancam terutama adalah aktivitas pertanian yang dinilai kurang menguntungkan dibanding aktivitas ekonomi lainnya.

Kabupaten Minahasa Tenggara merupakan pemekaran dari Kabupaten Minahasa Selatan pada tahun 2007. Di Kabupaten Minahasa Tenggara sendiri sektor pertanian dapat dikatakan menjadi salah satu penggerak utama dari roda perekonomian. Hal ini dapat kita pahami karena wilayah ini mempunyai lahan pertanian yang luas serta memiliki tingkat kesuburan yang tinggi. Salah satu bentuk dari pentingnya sektor pertanian di Kabupaten Minahasa Tenggara selain pada produktivitasnya adalah pada penyerapan tenaga kerja. Namun dengan pertumbuhan ekonomi yang semakin meningkat yang terjadi di Kabupaten Minahasa Tenggara ini menuntut adanya pembangunan berbagai infrastruktur sehingga permintaan lahan pertanian yang ada menjadi cukup besar. Akibatnya banyak lahan pertanian yang beralih fungsi untuk memenuhi kebutuhan tersebut.
Tabel 1. Luas Lahan Pertanian Kabupaten Minahasa Tenggara (Ha) Tahun 2008 - 2015

\begin{tabular}{ccc}
\hline Tahun & $\begin{array}{c}\text { Luas Lahan } \\
\text { Pertanian (Ha) }\end{array}$ & $\begin{array}{c}\text { Presentase Penurunan } \\
\text { Luas Lahan Pertanian } \\
(\%)\end{array}$ \\
\hline 2008 & 27.100 & 0 \\
2009 & 27.034 & $-0,24$ \\
2010 & 26.730 & $-1,12$ \\
2011 & 25.100 & $-6,10$ \\
2012 & 24.500 & $-2,39$ \\
2013 & 24.100 & $-1,63$ \\
2014 & 22.891 & $-5,02$ \\
2015 & 21.800 & $-4,77$ \\
\hline Sumber : BPS, SULUT Dalam Angka dari Tahun 2008 -
\end{tabular}

Alih fungsi lahan pertanian di Kabupaten Minahasa Tenggara beberapa tahun belakangan ini mengkhawatirkan. Dimana jika alih fungsi lahan produktif terus dilakukan, tentu bisa mengancam ketahanan pangan masyarakat di wilayah ini. Alih fungsi lahan hijau produktif khususnya untuk kebun sawah paling banyak terjadi di wilayah Tombatu Raya. Secara umum lahan persawahan ini di alih fungsikan menjadi lahan pemukiman oleh warga. beberapa tahun terakhir persawahan di wilayah Minahasa Tenggara berkurang mencapai ratusan hektar. Hal ini sendiri dikarenakan adanya kecenderungan penjualan sawah untuk pembangunan rumah. Apabila ini terus terjadi, maka akan mengancaman ketahanan pangan masyakat di seluruh pelosok Kabupaten Minahasa Tenggara.

Dengan peningkatan jumlah penduduk dari tahun ke tahun yang terjadi di Kabupaten Minahasa Tenggara menuntut jumlah produksi pangan yang semakin banyak. Sementara di sisi lain pertumbuhan ekonomi menuntut adanya permintaan jumlah lahan untuk pembangunan infrastruktur. Padahal peningkatan produktifitas sangat dipengaruhi oleh besarnya lahan yang digunakan. Disini faktor lahan pertanian mempunyai pengaruh yang sangat penting, sehingga jika keberadaanya menurun maka akan mengganggu jumlah produksi pangan yang ada. Seperti yang dikatakan oleh Sahid Susanto (2008), bahwa lahan mempunyai peran utama dalam menjaga stabilitas suplai pangan khususnya beras, meningkatkan fungsi ekologis, menciptakan aktivitas sosial dan ekonomi masyarakat pedesaan, wahana pembentuk peradaban masyarakat berbasis agraris. 
Menurut Irawan (2008), konversi lahan merupakan ancaman yang serius bagi keberlanjutan fungsi lahan untuk pertanian dan juga berdampak terhadap ketahanan pangan nasional karena dampak perubahannya bersifat permanen. Lahan pertanian yang telah dikonversi ke penggunaan lain di luar sektor pertanian akan sangat kecil peluangnya untuk berubah kembali menjadi lahan pertanian. Apabila masalah ini tidak ditangani dan diperhatikan secara khusus, maka akan menambah tingginya angka konversi lahan dan menyempitnya lahan subur pertanian di Kabupaten minahasa tenggara yang berdampak langsung terhadap ketahanan pangan. Menurut Martanto Rachmat (2012), apabila terjadi konversi lahan di suatu lokasi, maka luas lahan yang dikonversi di daerah tersebut akan semakin besar.

\section{Rumusan Masalah}

Pembangunan fisik yang terus - menerus dilakukan membuat terjadinya perubahan fungsi lahan. Banyak faktor-faktor yang mempengaruhi terjadinya alih fungsi lahan pertanian ke non pertanian.

Kabupaten Minahasa Tenggara merupakan pemekaran dari kabupaten minahasa selatan pada tahun 2007, Maka pembangunan berbagai fasilitas fasilitas pendukung dan infrastruktur publik sangat diperlukan di Kabupaten Minahasa Tenggara. Setiap pembangunan terlebih pembangunan fisik memerlukan lahan. pembangunan pemukiman serta perumahan juga semakin meningkat seiring pertumbuhan ekonomi dan pertumbuhan penduduk yang semakin tinggi, sehingga banyak lahan pertanian yang beralih fungsi. Oleh sebab itu penelitian perlu dilakukan untuk mengetahui dan menganalisis apa saja yang menjadi faktor faktor yang mempengaruhi terjadinya alih fungsi lahan di Kabupaten Minahasa Tenggara.

\section{Tujuan Penelitian}

Tujuan yang ingin dicapai dalam penelitian ini adalah untuk mengetahui dan menganalisis faktor-faktor yang mempengaruhi terjadinya alih fungsi lahan pertanian ke non pertanian di Kabupaten Minahasa Tenggara. Dilihat dari segi peningkatan jumlah penduduk, jumlah industri serta peningkatan pertumbuhan ekonomi, apakah berpengaruh terhadap penurunan luas lahan pertanian di Kabupaten Minahasa Tenggara.

\section{Manfaat Penelitian}

1. Manfaat penelitian ini adalah sebagai tambahan ilmu bagi peneliti mengenai faktor faktor yang mempengaruhi alih fungsi lahan.

2. Sebagai suatu bahan referensi bagi penelitian penelitian yanga akan datang

\section{METODE PENELITIAN}

\section{Waktu dan Tempat Penelitian}

Penelitian ini dilaksanakan di kabupaten Minahasa Tenggara, dimana telah terjadi alih fungsi lahan pertanian dengan melihat penurunan luas lahan pertanian dari tahun 2010 Penelitian ini telah dilakukan selama 4 bulan, dari tanggal 8 Januari 2016 sampai dengan 1 April 2016

\section{Metode Pengumpulan Data}

Data pada penelitian ini adalah data sekunder. Data sekunder adalah data yang diperoleh instansi terkait seperti BPS (Badan Pusat Statistik). Data sekunder misalnya berisi mengenai jumlah penduduk, PDRB, serta jumlah industri di Kabupaten Minahasa Tenggara dengan data time series

\section{Konsep Pengukuran Variabel}

Variabel-variabel yang akan diukur dalam penelitian ini adalah :

1. Luas lahan pertanian (Ha)

Pada penelitian ini penulis hanya berfokus pada luas lahan irigasi dan luas lahan perkebunan karena untuk alih fungsi lahan pertanian ke non pertanian di Kabupatn Minahasa Tenggara kedua lahan pertanian ini yang paling besar tingkat penurunan luas lahannya. jadi jumlah dari kedua luas lahan pertanian ini yang dijadiakan variabel tetap.

2. Jumlah Penduduk (jiwa)

Jumlah penduduk merupakan banyaknya penduduk yang tinggal dan menetap di Kabupaten Minahasa Tenggara selama 8 tahun terakhir. Jumlah ini terdiri dari penduduk laki-laki dan perempuan yang sudah tercatat oleh pemerintah setempat.

3. PDRB per kapita (Rp/tahun)

Dari PDRB kita dapat mengetahui apakah sektor-sektor yang didalamnya berpengaruh terhadap luas lahan pertanian atau tidak. Jumlah PDRB merupakan banyaknya pendapatan Kabupaten Minahasa 
Tenggara yang terdiri dari berbagai sektor yang ada. Untuk PDRB per kapita yaitu jumlah PDRB dibagi dengan jumlah penduduk yaitu gambaran rata-rata pendapatan yang diterima oleh setiap penduduk. Selain itu kita juga melihat pertumbuhan perekonomian pada daerah tersebut.

4. Jumlah Industri (unit)

Adanya peningkatan jumlah industri mendorong terjadinya peningkatan permintaan lahan. Semakin tinggi jumlah industri maka semakin tinggi penurunan luas lahan pertanian akibat terjadinya alih fungsi lahan ke non pertanian.

\section{Metode Analisis Data}

\section{Analisis Regresi Linear Berganda}

Metode analsis yang digunakan oleh peneliti untuk mencari pengaruh antara variabel bebas dengan variabel tak bebas. Dalam penelitian ini untuk menganalisis atau melihat pengaruh antara jumlah penduduk, PDRB per kapita, serta jumlah industri terhadap luas lahan pertanian di Kabupaten Minahasa Tenggara. Metode yang digunakan adalah metode analisis regresi linear berganda:

$$
\begin{array}{ll} 
& Y=a+\beta_{1} X_{1}+\beta_{2} X_{2}+\beta_{3} X_{3} \\
\text { Dimana } \mathrm{Y} & =\text { luas lahan pertanian (Ha) } \\
\mathrm{X}_{1} & =\text { Jumlah penduduk (jiwa) } \\
\mathrm{X}_{2} & =\text { PDRB per kapita (Rp) } \\
\mathrm{X}_{3} & \text { jumlah industri (unit) } \\
\mathrm{A} & \text { Konstanta, yaitu nilai Y jika } \mathrm{X}_{1} \\
& \text { dan } \mathrm{X}_{2}=0 \\
\mathrm{~B}_{1,} \beta_{2,} \beta_{3}= & \text { Koefisien regresi, yaitu nilai } \\
& \text { peningkatan atau penurunan } \\
& \text { variabel } \mathrm{Y} \text { yang didasarkan pada } \\
& \text { variabel } \mathrm{X}_{1} \text { dan } \mathrm{X}_{2}
\end{array}
$$

\section{Uji Koefisien Determinasi $\left(\mathbf{R}^{2}\right)$}

Koefisien determinasi $\left(\mathrm{R}^{2}\right)$, digunakan untuk mengukur seberapa besar variabel-variabel bebas dapat menjelaskan variabel terikat. Koefisien ini menunjukan seberapa besar variasi total pada variabel terikat yang dapat dijelaskan oleh variabel bebasnya dalam model regresi tersebut. Nilai dari koefisien determinasi ialah antara 0 hingga 1 . Nilai $\mathrm{R}^{2}$ yang mendekati 1 menunjukan bahwa variabel dalam model tersebut dapat mewakili permasalahan yang diteliti, karena dapat menjelaskan variasi yang terjadi pada variabel dependennya. Nilai $\mathrm{R}^{2}$ sama dengan atau mendekati 0 (nol) menunjukan variabel dalam model yang dibentuk tidak dapat menjelaskan variasi dalam variabel terikat. Nilai koefisien determinasi akan cenderung semakin besar bila jumlah variabel bebas dan jumlah data yang diobservasi semakin banyak.

\section{Uji F-Statistik}

Uji $F$ bertujuan untuk mengetahui ada atau tidaknya pengaruh simultan (bersama - sama) yang di berikan variabel bebas (X) terhadap variabel terikat $(\mathrm{Y})$. Dengan kriteria pengujian :

1. Jika nilai sig $<0,05$, atau $F$ hitung $>\mathrm{F}$ tabel maka terdapat pengaruh variabel $\mathrm{X}$ secara simultan terhadap variabel Y.

2. Jika nilai sig $>0,05$, atau $F$ hitung $<F$ tabel maka tidak terdapat pengaruh variabel $\mathrm{X}$ terhadap Variabel Y.

\section{Uji t-statistik}

Uji $\mathrm{T}$ bertujuan untuk mengetahui ada atau tidaknya pengaruh parsial (sendiri) yang diberikan variabel bebas $(\mathrm{X})$ terhadap variabel terikat $(\mathrm{Y})$. Dengan kriteria pengujian :

1. Jika nilai sig $<0,05$, atau $\mathrm{T}$ hitung $>\mathrm{T}$ tabel maka terdapat pengaruh variabel $\mathrm{X}$ terhadap variabel Y.

2. Jika nilai sig $>0,05$, atau $\mathrm{T}$ hitung $<\mathrm{T}$ tabel maka tidak terdapat pengaruh variabel $\mathrm{X}$ terhadap Variabel Y.

\section{HASIL DAN PEMBAHASAN}

\section{Deskripsi Daerah Penelitian}

Minahasa Tenggara adalah salah satu kabupaten di Provinsi Sulawesi Utara, Kabupaten Minahasa Tenggara memiliki Luas $730,62 \mathrm{Km}^{2}$. Letak Kabupaten Minahasa Tenggara terletak antara $124^{\circ} 32^{\prime} 56^{\prime \prime} \mathrm{BT}$ $124^{\circ} 57^{\prime} 3$ ' 'BT dan 0 50 '28' 'LU - 1'7'17' LU. Ibukota Kabupaten Minahasa Tenggara adalah Ratahan. Adapun batas-batas wilayah Kabupaten Minahasa Tenggara adalah sebagai berikut :

a. Sebelah Utara berbatasan dengan Kecamatan Amurang Timur dan Kecamatan Amurang Kabupaten Minahasa Selatan.

b. Sebelah Timur berbatasan dengan Kecamatan Langowan Kabupaten Minahasa dan Laut Maluku. 
c. Sebelah Selatan berbatasan dengan Laut Maluku dan Kecamatan Kotabunan Kabupaten Bolaang Mongondow.

d. Sebelah Barat berbatasan dengan Kecamatan Ranoyapo dan Kecamatan Kumelembuai Kabupaten Minahasa Selatan.

Kabupaten MinahasaTenggara terdiri atas 12 kecamatan, antara lain : Kecamatan Ratatotok, Kecamatan Pusomaen, Kecamatan Belang, Kecamatan Ratahan, Kecamatan Pasan, Kecamatan Ratahan Timur, Kecamatan Tombatu, Kecamatan Tombatu Timur, Kecamatan Tombatu Utara, kecamatan Touluaan, Kecamatan Touluaan Selatan.

\section{Luas Lahan Pertanian Menurut Penggunaannya \\ di Kabupaten Minahasa Tenggara}

Dengan meningkatnya kualitas hidup saat ini secara otomatis kebutuhan hidup juga meningkat sehingga pembangunan pemukiman dan pembangunan sarana - sarana lainnya bertambah sementara ketersediaan lahan yang tetap membuat peralihan lahan dari fungsi sebelumnya tidak dapat dihindari. Berdasarkan hal tersebut berikut tabel dibawah ini yang menunjukan penurunan luas lahan pertanian di Kabupaten Minahasa Tenggara terlihat pada 6 tahun terakhir.

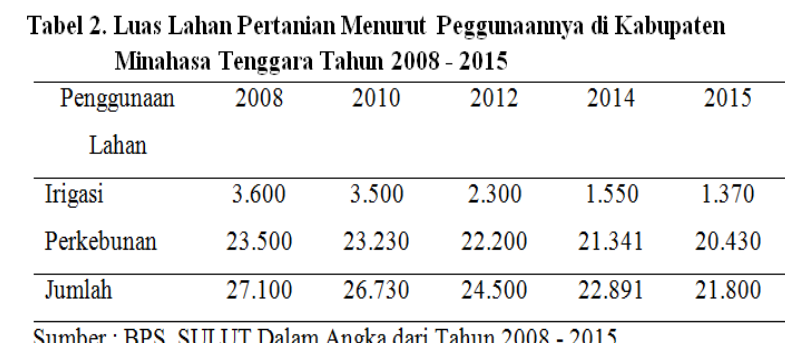

Berdasarkan Tabel 2 dapat di lihat bahwa tingkat penurunan luas lahan pertanian yang terjadi di Kabupaten Minahasa Tenggara dari tahun 2008 sampai 2015 sangat besar. pada tahun 2008 sampai tahun 2010 terjadi penurunan luas lahan pertanian yang sebelumnya $27.100 \mathrm{Ha}$ menjadi 26.730 Ha telah terjadi penurunan sebesar $1,36 \%$. Pada periode ini penurunan luas lahan terjadi bukan tanpa alasan, penurunan terjadi karena seiring Kabupaten Minahasa Tenggara yang di periode ini masih merupakan kabupaten yang baru yang mengharuskan di banggunnya berbagai infrastruktur publik baik itu kantor kantor pemerintahan maupun jalan dan berbagai infrastruktur publik lainnya. Penurunan terbesar terjadi pada periode tahun 2012 sampai 2015 berkurang sebesar $11,02 \%$, yang pada tahun 2012 luas lahan irigasi dan perkebunan memiliki luas $24.500 \mathrm{Ha}$ menjadi $21.800 \mathrm{Ha}$ pada tahun 2015 penurunan ini terjadi karena adanya peningkatan jumlah penduduk yang ada di Kabupaten Minahasa Tenggara sehingga mengakibatkan meningkatnya konversi lahan pertanian terutama lahan perkebunan.

Hampir semua kecamatan di Kabupaten Minahasa Tenggara melakukan konversi lahan pertanian hal ini di lakukan untuk perluasan lahan pemukiman, jalan dan berbagai infrastruktur publik. Untuk lahan persawahan konversi terbesar terjadi di kecamatan tombatu raya, belang dan touluaan, lahan - lahan persawahan ini di alih fungsikan menjadi lahan pemukiman dan tempat usaha seperti rumah makan.

\section{Jumlah Penduduk}

\section{Kabupaten Minahasa Tenggara}

Kabupaten Minahasa Tenggara menjadi salah satu kabupaten yang jumlah penduduknya beberapa tahun terakhir menigkat di Sulawesi Utara. Semakin bertambahnya jumlah penduduk cukup menjadi perhatian karena akan menyebabkan terjadinya penurunan luas lahan hal ini terjadi karena timbulnya alih fungsi lahan pertanian ke non pertanian karena dengan meningkatnya jumlah penduduk maka kebutuhan untuk lahan sebagai tempat manusia beraktifitas meningkat. Tabel di bawah ini menunjukan jumlah penduduk di Kabupaten Minahasa Tenggara dari tahun 2008-2015.

Tabel 3. Jumlah Penduduk di Kabupaten Minahasa

\begin{tabular}{ccc} 
& Tenggara dari Tahun & 2008-2015 \\
\hline Tahun & $\begin{array}{c}\text { Jumalah Penduduk } \\
\text { Mianahasa Tenggara }\end{array}$ & $\begin{array}{c}\text { Presentase Peningkatan } \\
\text { Jumlah Penduduk (\%) }\end{array}$ \\
\hline 2008 & 95.145 & 0 \\
2009 & 95.200 & 0,05 \\
2010 & 97.100 & 1,99 \\
2011 & 100.221 & 3,21 \\
2012 & 101.761 & 1,53 \\
2013 & 102.226 & 0,45 \\
2014 & 103.818 & 1,55 \\
2015 & 104.536 & 0,69 \\
\hline
\end{tabular}

Sumber: BPS, Minahasa Tenggara Dalam Angka dari Tahun $2008-2015$

Tabel 3 menunjukkan bahwa secara umum jumlah penduduk di Kabupaten Minahasa Tenggara setiap tahunnya menggalami peningkatan, kelahiran yang cukup tinggi 
merupakan faktor penyebab bertambahnya jumlah penduduk setiap tahunnya. Dengan bertambahnya jumlah penduduk akan menyebabkan aktifitas penduduk juga meningkat sehingga membutuhkan lahan untuk pemukiman baru sementara lahan yang ada di Kabupaten Minahasa Tenggara terbatas sehingga menggorbankan lahan pertanian untuk di alih fungsikan menjadi lahan pemukiman dan lain-lain.

\section{PDRB Menurut Lapangan Usaha Berdasarkan Lapangan Usaha Atas Dasar Harga Konstan Kabupaten Minahasa Tenggara}

Dengan melihat Tabel 4 kita akan melihat apakah sektor-sektor yang di dalamnya mempengaruhi terhadap terjadinya penurunan luas lahan pertanian di kabupaten minhasa tenggara. Dari PDRB juga kita dapat melihat pertumbuhan ekonomi derah tersebut.

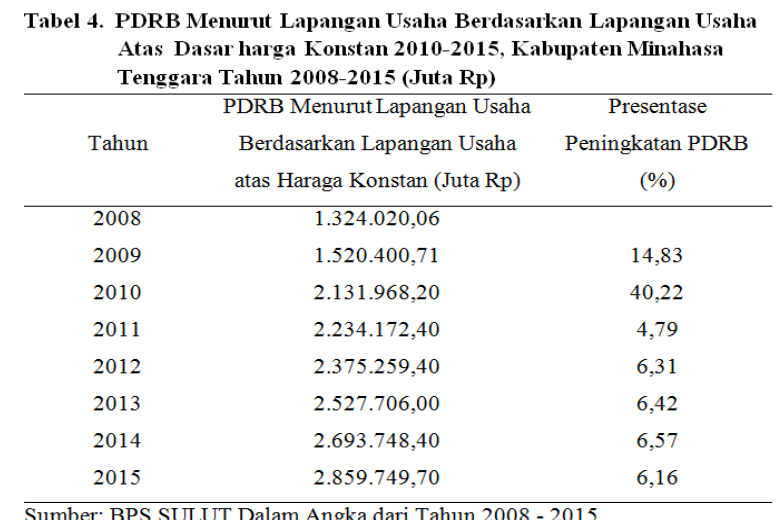

Di Indonesia sektor pertanian mempunyai peran yang sangat penting dalam pertumbuhan perekonomian, begitu juga yang terjadi di Kabupaten Minahasa Tenggara. Dari tabel yang ada dapat di lihat bahwa PDRB di Kabupaten Minahasa Tenggara setiap tahunnya mengalami peningkatan. Posisi sektor pertanian berada di posisi pertama sebelum sektor industri penggolahan Hal ini menunjukan bahwa sektor pertanian masih menjadi salah satu penggerak utama dari perekonomian di Kabupaten Minahasa Tenggara. Peningkatan PDRB pada sektor pertanian tersebut dapat dimenggerti karena luas lahan pertanian di Kabupaten Minahasa Tenggara cukup luas. Akan tetapi seiring majunya perkembangan zaman banyak lahan pertanian yang beralih fungsi menjadi lahan non pertanian. Peralihan lahan tersebut banyak di gunakan untuk pembanggunan pemukiman baru, rumah makan maupun pembanggunan berbagai infrastruktur yang ada.

\section{Jumlah Industri \\ di Kabupaten Minahasa Tenggara}

Jumlah industri merupakan banyaknya pertumbuhan industri yang tercatat di dinas perindustrian, perdagangan dan koprasi di Kabupaten Minahasa Tenggara yang di publikasikan oleh BPS. Industtri tersebut terdiri dari dari industri rumah tangga (Jumlah tenaga kerja $<5$ orang), industri kecil (jumlah tenaga kerja antara 20 sampai 90 orang), serta industri besar (jumlah tenaga kerja $>100$ orang). Tabel 5 menunjukan jumlah usaha kecil, menengah dan usaha besar yang ada di Kabupaten Minahasa Tenggara.

\begin{tabular}{|c|c|c|}
\hline \multirow[b]{2}{*}{ Tahun } & upaten Minahasa Tenggara Tahum 2008- & \\
\hline & $\begin{array}{l}\text { Jumlah Usaha Kecil, Usaha Menenggah, } \\
\qquad \text { dan Usaha Besar } \\
\text { di Kabupaten Minahasa Tenggara (Unit) }\end{array}$ & $\begin{array}{l}\text { Presentase Jumlah } \\
\text { perubahan Jumalh } \\
\text { Industri (\%) }\end{array}$ \\
\hline 2008 & 229 & \\
\hline 2009 & 250 & 0,09 \\
\hline 2010 & 467 & 0,87 \\
\hline 2011 & 454 & $-0,03$ \\
\hline 2012 & 710 & 0,56 \\
\hline 2013 & 1.212 & 0,71 \\
\hline 2014 & 1.136 & $-0,06$ \\
\hline 2015 & 1.229 & 0,08 \\
\hline
\end{tabular}

Sumber : BPS, Mianahasa Tenggara Dalam Angka dari Tahun 2008 - 2015

Tabel 5 menujukan bahwa telah terjadi peningkatan jumlah usaha kecil, usaha menengah, maupun Usaha besar di Kabupaten Minahasa Tenggra pada Tahun 2008 hingga tahun 2010, yang tahun 2008 indutri berjumlah 229 unit meningkat menjadi 467 unit di tahun 2010. Namun Pada tahun 2011 jumlah industri di Kabupaten Minahasa Tenggara mengalami penurunan sebesar $0,03 \%$ yang pada tahun 2010 berjumlah 567 unit turun menjadi 454 unit di tahun 2011. Pada tahun berikutnya jumlah industri terus mengalami peningkatan hingga tahun 2013. Penurunan jumlah industri kembali terjadi pada tahun 2014 penurunan kali ini sebesar 0,06\% yang pada tahun 2013 jumlah industri sebanyak 1.212 unit turun menjadi 1.136 unit di tahun 2014. Pada tahun 2015 jumlah industri kembali mengalami peningkatan menjadi 1.229 unit. Dari penjelasan pada tabel 5 menyatakan adanya peningkatan terhadap jumlah industri di Kabupaten Minahasa Tenggara. Untuk itu dalam penelitian ini, akan di lihat penggaruh antara jumlah industri dengan luas lahan pertanian yang ada di Kabupaten Minahasa Tenggara. 


\section{Hasil Analisis Model Regresi}

Berdasarkan Hasil olahan data menggunakan SPSS 20, dengan nilai yang dimasukan dalam model tersebut, sehingga persamaan yang di peroleh adalah sebagai berikut:

$$
\begin{array}{r}
Y=81392,307-0,577 \mathrm{X}_{1}+0,001 \mathrm{X}_{2}-0,696 \mathrm{X}_{3} \\
(\mathrm{p}=0,048) \quad(\mathrm{p}=0,557) \quad(\mathrm{p}=0,590)
\end{array}
$$

Berdasarkan analisis data di atas dalam penelitian mengenai faktor-faktor yang mempengaruhi alih fungsi lahan pertanian di Kabupaten Minahasa Tenggara ada beberapa variabel independen yang digunakan untuk mendukung penelitian ini. Variabel independen tersebut antara lain jumlah penduduk, PDRB per kapita, serta jumlah industri. Adapun analisis tiap variabelnya adalah sebagai berikut.

a. Variabel Jumlah Penduduk

Jumlah penduduk yang ada di Kabupaten Minahasa Tenggara setiap tahun selalu mengalami pertambahan besarnya nilai koefisien parameter jumlah penduduk sebesar 0,577 ini berarti bahwa setiap ada peningkatan jumlah penduduk satu jiwa maka akan terjadi penurunan luas lahan pertanian sebesar 0,577 Ha koefisien regresi tersebut bernilai negatif, sehingga dapat dikatakan bahwa arah pengaruh variabel jumlah penduduk terhadap luas lahan adalah negatif.

\section{b. Variabel PDRB per kapita}

Besarnya koefisien PDRB per kapita 0,001 yang berarti jika PDRB per kapita bertambah satu juta rupiah maka akan terjadi penambahan luas lahan pertanian sebesar 0,001 Ha. Koefisien regresi tersebut bernilai positif sehingga dapat dikatakan bahwa pengaruh variabel PDRB per kapita terhadap luas lahan pertanian adalah positif. Besarnya PDRB merupakan pendapatan daerah dari berbagai sektor yang ada. Pada kabupaten minahasa tenggara pendapatan rata rata penduduk yang meningkat mungkin bukan berasal dari sektor pertanian.

c. Variabel Jumlah Industri

Banyaknya industri di Kabupaten Minahasa Tenggara semakin meningkat baik itu industri besar, sedang, menengah, maupun industri rumah tangga. Besarnya koefisien Jumlah industri sebesar $-0,696$ yang berarti setiap ada peningkatan jumlah industri satu unit maka akan terjadi penurunan luas lahan pertanian sebesar 0,696 dapat di katakan bahwa pengaruh Variabel jumlah industri terhadap luas lahan yang ada berpengaruh negatif. Namun, dalam penelitian ini jumlah industri terbukti tidak signifikan maka jumlah industri tidak berpengaruh terhadap penurunan luas lahan pertanian yang ada.

Pada Kabupaten Minahasa Tenggara ini, peningkatan yang terjadi bukan pada industri besar melainkan hanya pada industri rumah tangga, industri kecil dan menengah yang memang tidak memerlukan lahan yang luas.

\section{Analisis Koefisien Kolerasi $\mathbf{R}$ dan Koefisien Determinasi $\left(\mathbf{R}^{2}\right)$}

Berdasarkan hasil perhitungan dengan menggunakan bantuan program SPSS 20 seperti yang ada pada lampiran 1 dapat di lihat bahwa nilai $\mathrm{R}$ yang di hasilkan adalah sebesar 0,981 atau $98,1 \%$. artinya hubungan antara jumlah penduduk, PDRB per kapita, dan jumlah industri dengan luas lahan pertanian mempunyai hubungan erat. Nilai $\mathrm{R}$ square adalah 0,962 atau $96,2 \%$. artinya pengaruh variabel Jumlah penduduk $\left(\mathrm{x}_{1}\right), \operatorname{PDRB}\left(\mathrm{x}_{2}\right)$, jumlah industri $\left(\mathrm{x}_{3}\right)$ pada penurunan luas lahan adalah sebesar $96,2 \%$ dan sisanya sebesar $3,8 \%$ di pengaruhi variabel lain.

\section{Uji F}

Berdasarkan Hasil analisis regresi pada lampiran diketahui nilai signifikansi untuk pengaruh variabel $\mathrm{X} 1, \mathrm{X} 2$, dan $\mathrm{X} 3$ secara bersama sama terhadap variabel $\mathrm{Y}$ adalah sebesar $0,003<0,05$ dan nilai $\mathrm{F}$ hitung 33,580 $>5,41$, sehingga dapat di simpulkan bahwa X1, $\mathrm{X} 2$ dan X3 secara bersama sama berpengaruh secara nyata terhadap penurunan luas lahan pertanian di Kabupaten Minahasa Tenggara.

\section{Uji T}

Uji $\mathrm{T}$ bertujuan untuk mengetahui ada atau tidaknya pengaruh yang diberikan setiap variabel bebas terhadap variabel terikat dalam model regresi yang sudah di hasilkan. Dari hasil uji T pada lampiran di ketahui bahwa :

1. Diketahui nilai sig untuk pengaruh $\mathrm{X} 1$ terhadap $\mathrm{Y}$ adalah sebesar $0,048<0,05$ dan 
nilai $\mathrm{T}$ hitung 2,812 > $\mathrm{T}$ tabel 2,776, sehingga dapat disimpulkan bahwa X1 di terima yang berarti jumlah penduduk berpengaruh nyata terhadap penurunan luas lahan pertanian di Kabupaten Minahasa Tenggara.

2. Diketahui nilai sig untuk pengaruh $\mathrm{X} 2$ terhadap $\mathrm{Y}$ adalah sebesar $0,557>0,05$ dan nilai $\mathrm{T}$ hitung $0,641<\mathrm{T}$ tabel 2,776, sehingga dapat disimpulkan bahwa X2 ditolak yang berarti PDRB per kapita tidak berpengaruh nyata terhadap penurunan luas lahan pertanian di Kabupaten Minahasa Tenggara.

3. Diketahui nilai sig untuk pengaruh $\mathrm{X} 3$ terhadap $\mathrm{Y}$ adalah sebesar $0,590>0,05$ dan nilai $\mathrm{T}$ hitung $-0,585<\mathrm{T}$ tabel 2,776, sehingga dapat disimpulkan bahwa X3 ditolak yang berarti tidak terdapat pengaruh X3 terhadap Y, ini dikarenakan industri yang termasuk di dalamnya sudah termasuk industri rumahan yang mungkin tidak membutuhkan lahan yang luas untuk usahanya.

Dari hasil penelitian yang di analisis di atas, variabel jumlah penduduk berpengaruh secara nyata terhadap penurunan luas lahan pertanian di Kabupaten Minahasa Tenggara, pesatnya peningkatan jumlah penduduk telah meningkatkan permintaan akan lahan untuk di jadikan lahan pemukiman dan perumahan. Peningkatan taraf hidup masyarakat juga turut berperan menciptakan tambahan peningkatan akan lahan akibat peningkatan intensitas kegiatan masyarakat seperti pusat perbelanjaan, jalan, tempat rekreasi dan sarana umum lainnya.

\section{KESIMPULAN DAN SARAN}

\section{Kesimpulan}

1. Jumlah penduduk, PDRB per kapita, dan jumlah industri hanya jumlah penduduk yang memberikan pengaruh secara siknifikan terhadap penurunan luas lahan pertanian yang ada di Kabupaten Minahasa Tenggara. Dimana semakin besar jumlah penduduk yang ada maka luas lahan pertanian cenderung semakin menurun.
2. Meningkatnya pendapatan masyarakat cenderung mendorong perluasan lahan untuk pusat perbelanjaan, pemukiman, tempat usaha seperti rumah makan dan infrastruktur lainnya. Perluasan lahan tersebut patut di duga di alih fungsikan dari lahan pertanian.

\section{Saran}

1. Pemerintah perlu untuk membatasi atau lebih memperketat aturan dan ijin untuk alih fungsi lahan dari lahan pertanian ke non pertanian.

2. Perlu adanya monitoring berkelanjutan dari pemerintah Kabupaten Minahasa Tenggara yang benar benar efektif dan koordinasi antar dinas terkait dalam permasalahan alih fungsi lahan pertanian hendaknya lebih ditingkatkan lagi.

\section{DAFTAR PUSTAKA}

Adiandri, R. S., Nugraha, S., \& Rachmat, R. 2017. Karakteristik Mutu Fisikokimia Jamur Merang (Volvarella Volvacea) Selama Penyimpanan Dalam Berbagai Jenis Larutan Dan Kemasan. Jurnal Penelitian Pascapanen Pertanian, 9(2), 77-87.

Irawan, B. 2008. Konversi Lahan Sawah: Potensi Dampak, Pola Pemanfaatannya, dan Faktor Determinan, Forum Penelitian Agro Ekonomi Volume 23, Nomor 1, Juni 2005. Pusat Analisis Sosial Ekonomi dan Kebijakan Pertanian. Bogor.

Maharrani, R. H., Syukur, A., \& Tyas Catur, P. 2010. Penerapan Metode Analytical Hierarchi Process Dalam Penerimaan Karyawan Pada PT. Pasir Besi Indonesia. Jurnal Teknologi Informasi, 6(1), 102-114.

Susanto, S. 2008. Strategi Pengendalian Alih Fungsi Lahan Beririgasi: Studi Kasus Kabupaten Banyumas. 